\title{
Clinical Outcomes of ProChondrix® Osteochondral Allograft in the Knee: A Case Series
}

Michael S. Barnum ( $\square$ michael.barnum@med.uvm.edu )

University of Vermont https://orcid.org/0000-0001-9885-0449

Evan D. Boyd

University of Vermont College of Medicine

Annabelle P. Davey

University of Vermont College of Medicine

Andrew Slauterbeck

University of Vermont

James R. Slauterbeck

University of South Alabama College of Medicine

\section{Research article}

Keywords: osteochondral allograft, cartilage, knee surgery, cartilage repair

Posted Date: June 29th, 2021

DOI: https://doi.org/10.21203/rs.3.rs-625313/v1

License: () (i) This work is licensed under a Creative Commons Attribution 4.0 International License. Read Full License 


\section{Abstract}

\section{Purpose}

Focal articular cartilage injuries are common and may lead to progression of osteoarthritis. The complications associated with traditional treatment strategies have influenced the development of new biotechnologies, such as the ProChondrix ${ }^{\circledR}$ osteochondral allograft. Clinical evidence on the outcomes associated with ProChondrix ${ }^{\circledR}$ osteochondral allografts are limited. Thus, the primary purpose of this study was to evaluate the clinical outcomes following treatment of an isolated cartilage defect with a ProChondrix ${ }^{\circledR}$ osteochondral allograft implant.

\section{Methods}

Retrospective analysis of patients who underwent a cartilage restoration procedure using ProChondrix ${ }^{\circledR}$ osteochondral allograft has been performed. Patients completed patient-reported outcome surveys which included the Knee injury and Osteoarthritis Outcome Score (KOOS), consisting of the 5 subscales of Pain, Symptoms, Activities of Daily Living, Sports and Recreation, and Quality of Life, the Marx Activity Scale, and the visual analog pain scale.

Results

Six patients underwent a cartilage restoration procedure using ProChondrix ${ }^{\circledR}$ between January 2016 and December 2019. Three males and three females were included with a median age of 33.5 years (range 18-48 years). The median follow-up duration was 15 months (range 9-24 months). There were 4 patellar grafts, 1 medial femoral condyle graft, and 1 lateral femoral condyle graft, with a median defect size of $18.5 \mathrm{~mm}$ (range $13-20 \mathrm{~mm}$ ). At the most recent clinical follow-up, all six patients were pain free and all patients had returned to pre-op activity level.

\section{Conclusion}

To our knowledge, this is the first study to report the clinical outcome, activity level, and patient orientated outcomes in a case series of patients following treatment of an isolated cartilage defect with a ProChondrix ${ }^{\circledR}$ osteochondral allograft implant. Our study demonstrates promising short-term results in patient reported clinical outcome scores.

\section{Introduction}

Focal articular cartilage injuries are common and present in up to two-thirds of patients undergoing knee arthroscopy [6]. These injuries may be caused by acute trauma or degenerative processes and can cause significant functional impairment leading to progression of osteoarthritis[15]. Following injury, articular cartilage has a limited ability to spontaneously heal and recover due to its lack of vasculature and cellularity making it a challenging problem to treat[3].

Traditional treatment strategies for focal cartilage defects include microfracture (MF), autologous chondrocyte implantation (ACI), osteochondral autograft (OATS), and osteochondral allograft (OCA)[15]. While these techniques have contributed to the field of cartilage repair, each have their own pitfalls. Most of these surgical procedures result in the generation of fibrocartilage, hyaline-like articular cartilage, or are limited by cadaver availability, shelf life, and disease transmission[4]. The complications associated with these traditional treatment strategies and the complexity of hyaline cartilage regeneration have influenced the development of new biotechnologies.

Among these newly emerging biotechnologies, ProChondrix ${ }^{\circledR}$ Cartilage Restoration Matrix is an osteochondral allograft disc implant which contains extracellular matrix, native growth factors, and viable chondrocytes that can aid in cartilage repair and help promote chondrogenesis[16]. ProChondrix presents as a unique option for contained cartilage defects as it is readily available, can reconstitute complex articular surface geometry, restore adequate cartilage depth, and is performed in a single stage procedure[16]. To date, clinical evidence on the short-term or long-term outcomes associated with ProChondrix ${ }^{\circledR}$ osteochondral allograft are limited[1]. 
The primary purpose of this study was to evaluate the short-term clinical outcomes following ProChondrix ${ }^{\circledR}$ osteochondral allograft implant; we undertook this by assessing subjective outcomes of pain, function, activity level, and quality of life among a case series of patients.

\section{Methods}

\section{Patient selection}

We retrospectively identified six patients who had underwent a cartilage restoration procedure using ProChondrix ${ }^{\circledR}$ osteochondral allograft by a single surgeon between January 2016 and December 2019. Inclusion criteria were patients between 18-60 years of age who underwent bone marrow stimulation plus ProChondrix ${ }^{\circledR}$ osteochondral allograft to treat an articular cartilage defect of the knee joint. Exclusion criteria included patients with any contraindications for MRI or CT and patients with less than 6 months clinical follow-up.

Demographic data were collected for all patients, including: age, sex, body mass index, workers compensation status, level of athletics prior to injury, previous injuries to same knee, previous surgeries to same knee, mechanism of injury, pain, and comorbidities. Intraoperative data collected included defect location, defect side, defect size, graft fixation technique, and concomitant procedures. Postoperative data collected included pain scale and all patients were contacted to complete patientreported outcome (PRO) assessments.

According to the policy defining activities which constitute research at our institution, this work met criteria for operational improvement activities exempt from ethics review. The original intent of this review was for a quality improvement project to determine if we should continue to utilize this product.

\section{Surgical Technique}

The surgical procedure was performed with the patient in a supine position with a tourniquet on the proximal ipsilateral thigh. A parapatellar arthrotomy was performed and the cartilage defect was identified. The ProChondrix ${ }^{\circledR}$ sizing instrument was used to determine the cartilage lesion size and ensure the appropriately sized ProChondrix ${ }^{\circledR}$ allograft was used. Using the ProChondrix ${ }^{\circledR}$ Disposable Instrument set that corresponds with the desired size ProChondrix $\AA^{\circledR}$ allograft, all damaged and loose cartilage was excised on the osteochondral defect with debridement to the subchondral bone layer. Bone marrow stimulation via microfracture was then performed at the base of the defect. The ProChondrix ${ }^{\circledR}$ allograft was then implanted into the osteochondral defect and Tisseel (Baxter, Deerfield, IL) fibrin glue was used for fixation. Postoperatively, patients were made non-weightbearing and placed in a knee extension brace for 48 hours. Full passive range of motion was permitted for one month using a continuous passive motion machine. If the cartilage defect was on the patella, the patients could bear $50 \%$ weight in extension for 6 weeks. If the cartilage repair was on the distal femur, the patients were made touchdown weight bearing for 6 weeks. After 6 weeks, patients gradually increased their amount of weight bearing and began strength recovery by following a protocol lead by a physical therapist.

\section{Outcome Assessment}

Subjective outcomes were assessed using PRO assessments. PROs included the Knee injury and Osteoarthritis Outcome Score (KOOS), consisting of the 5 subscales of Pain, Symptoms, Activities of Daily Living, Sports and Recreation, and Quality of Life; and the Marx Activity Scale. These scores were evaluated postoperatively, and the most recent available postoperative outcome data were used for the study. PROs were administered via REDCaps electronic surveys.

\section{Statistical Analysis}

Means, medians, and ranges were calculated to summarize patient characteristics, subjective patient outcomes (KOOS, Marx Activity Scale, and pain scale), and follow-up data.

\section{Results}


A total of 6 patients who underwent a bone marrow stimulation plus ProChondrix osteochondral allograft to treat an articular cartilage defect were included in the present study. Patient demographics and clinical details are presented in Tables 1 and 2. Of the 6 patients, there were 3 females and 3 males, with median age of 33.5 years (range 18-48 years) and a median body mass index of $30 \mathrm{~kg} / \mathrm{m}^{2}$ (range $21-34 \mathrm{~kg} / \mathrm{m}^{2}$ ). All patients had a minimum follow-up of 6 months. The median follow-up duration was 15 months (range 9-24 months).

Table 1

Demographic Data

\begin{tabular}{|c|c|c|c|c|c|c|c|c|c|}
\hline $\begin{array}{l}\text { Patient } \\
\#\end{array}$ & Sex & Age & BMI & WC? & $\begin{array}{l}\text { Level of } \\
\text { Athletics } \\
\text { before injury }\end{array}$ & $\begin{array}{l}\text { Previous } \\
\text { injuries to } \\
\text { same knee }\end{array}$ & $\begin{array}{l}\text { Previous surgeries } \\
\text { to same knee }\end{array}$ & $\begin{array}{l}\text { Mechanism } \\
\text { of injury }\end{array}$ & Comorbidities \\
\hline 1 & $\mathrm{~F}$ & 43 & 33 & No & ADLs & $\begin{array}{l}\text { Patellar } \\
\text { cartilage } \\
\text { injury }\end{array}$ & $\begin{array}{l}\text { Patellar } \\
\text { chondroplasty }\end{array}$ & $\begin{array}{l}\text { Patellar } \\
\text { instability }\end{array}$ & $\begin{array}{l}\text { Obesity, } \\
\text { asthma, } \\
\text { hypertension, } \\
\text { anxiety }\end{array}$ \\
\hline 2 & $M$ & 24 & 31 & No & ADLs & No & No & Insidious & Obesity \\
\hline 3 & $M$ & 21 & 21 & No & $\begin{array}{l}\text { Collegiate } \\
\text { sports } \\
\text { (soccer, } \\
\text { skiing) }\end{array}$ & $\begin{array}{l}\text { Intraarticular } \\
\text { loose bodies }\end{array}$ & $\begin{array}{l}\text { Knee arthroscopy, } \\
\text { patellar } \\
\text { chondroplasty, } \\
\text { removal of loose } \\
\text { bodies }\end{array}$ & $\begin{array}{l}\text { Patellar } \\
\text { dislocations }\end{array}$ & None \\
\hline 4 & $\mathrm{~F}$ & 18 & 29 & No & $\begin{array}{l}\text { High School } \\
\text { sports } \\
\text { (basketball) }\end{array}$ & No & No & $\begin{array}{l}\text { Patellar } \\
\text { dislocations }\end{array}$ & $\begin{array}{l}\text { Obesity, } \\
\text { hyperlipidemia }\end{array}$ \\
\hline 5 & $\mathrm{~F}$ & 48 & 34 & No & ADLs & $\begin{array}{l}\text { Medial } \\
\text { meniscal } \\
\text { injury }\end{array}$ & $\begin{array}{l}\text { Partial medial } \\
\text { meniscectomy }\end{array}$ & Insidious & $\begin{array}{l}\text { Obesity, } \\
\text { hyperlipidemia, } \\
\text { GERD }\end{array}$ \\
\hline 6 & $M$ & 45 & 27 & No & $\begin{array}{l}\text { Recreational } \\
\text { sports } \\
\text { (hiking, } \\
\text { basketball) }\end{array}$ & $\begin{array}{l}\text { Patellar } \\
\text { cartilage } \\
\text { injury, MFC } \\
\text { cartilage } \\
\text { injury }\end{array}$ & $\begin{array}{l}\text { Patellar cartilage } \\
\text { chondroplasty, } \\
\text { medial femoral } \\
\text { chondroplasty, } \\
\text { removal of loose } \\
\text { bodies }\end{array}$ & Insidious & $\begin{array}{l}\text { Hypertension, } \\
\text { GERD }\end{array}$ \\
\hline
\end{tabular}

Table 2

Surgery Characteristics

\begin{tabular}{|c|c|c|c|c|c|}
\hline $\begin{array}{l}\text { Patient } \\
\#\end{array}$ & $\begin{array}{l}\text { Side } \\
\text { (R/L) }\end{array}$ & $\begin{array}{l}\text { Location } \\
\text { (MFC/LFC/MTP/LTP/patella) }\end{array}$ & $\begin{array}{l}\text { Defect } \\
\text { size } \\
(\mathrm{mm})\end{array}$ & $\begin{array}{l}\text { Graft } \\
\text { fixation }\end{array}$ & Concomitant procedures to same knee \\
\hline 1 & L & Patella & 20 & Tisseel & $\begin{array}{l}\text { Tibial tubercle anteromedial osteotomy and } \\
\text { lateral release }\end{array}$ \\
\hline 2 & $\mathrm{~L}$ & MFC & 17 & Tisseel & $\begin{array}{l}\text { Medial meniscectomy and transplant, } \mathrm{ACL} \\
\text { reconstruction (bone-tendon-bone allograft) }\end{array}$ \\
\hline 3 & $\mathrm{R}$ & Patella & 20 & Tisseel & Tibial tubercle osteotomy and lateral release \\
\hline 4 & $\mathrm{~L}$ & Patella & 20 & Tisseel & Tibial tubercle osteotomy and lateral release \\
\hline 5 & $\mathrm{R}$ & LFC & 13 & Tisseel & No \\
\hline 6 & $\mathrm{R}$ & Patella & 17 & Tisseel & No \\
\hline
\end{tabular}

In this case series, there were 4 patellar grafts, 1 medial femoral condyle graft, and 1 lateral femoral condyle graft, with a median defect size of $18.5 \mathrm{~mm}$ (range $13-20 \mathrm{~mm}$ ). In addition to bone marrow stimulation plus ProChondrix osteochondral allograft transplant in all patients, 3 patients underwent tibial tubercle anteromedial osteotomy and lateral release and 1 patient underwent medial meniscal meniscectomy with meniscal transplant and ACL reconstruction. 
At the most recent clinical follow-up, all six patients were pain free and all patients had returned to pre-op activity level. Postoperative KOOS and Marx scores are shown in Table 3.

Table 3

Patient reported outcomes

\begin{tabular}{|c|c|c|c|c|c|c|c|c|c|c|c|}
\hline $\begin{array}{l}\text { Patient } \\
\#\end{array}$ & $\begin{array}{l}\text { Time to } \\
\text { f/u } \\
\text { (months) }\end{array}$ & $\begin{array}{l}\text { KOOS } \\
\text { (symptoms) }\end{array}$ & $\begin{array}{l}\text { KOOS } \\
\text { (pain) }\end{array}$ & $\begin{array}{l}\text { KOOS } \\
\text { (daily } \\
\text { living) }\end{array}$ & $\begin{array}{l}\text { KOOS } \\
\text { (sports) }\end{array}$ & $\begin{array}{l}\text { KOOS } \\
\text { (quality } \\
\text { of life) }\end{array}$ & $\begin{array}{l}\text { KOOS } \\
\text { (total) }\end{array}$ & $\begin{array}{l}\text { Marx } \\
\text { score }\end{array}$ & $\begin{array}{l}\text { Pre- } \\
\text { op } \\
\text { pain }\end{array}$ & $\begin{array}{l}\text { Post-op } \\
\text { pain (6 } \\
\text { months) }\end{array}$ & $\begin{array}{l}\text { Return } \\
\text { to } \\
\text { preop } \\
\text { activity } \\
\text { level }\end{array}$ \\
\hline 1 & 24 & 75 & 100 & 84 & 70 & 44 & 75 & 4 & 5 & 0 & Yes \\
\hline 2 & 18 & 61 & 89 & 93 & 55 & 31 & 66 & 5 & 0 & 0 & Yes \\
\hline 3 & 24 & 79 & 81 & 96 & 55 & 50 & 72 & 8 & 2 & 0 & Yes \\
\hline 4 & 12 & 86 & 92 & 97 & 75 & 75 & 85 & 9 & 0 & 0 & Yes \\
\hline 5 & 9 & 79 & 92 & 99 & 90 & 69 & 86 & 0 & 6 & 0 & Yes \\
\hline 6 & 11 & 89 & 94 & 99 & 90 & 75 & 89 & 11 & 3 & 0 & Yes \\
\hline $\begin{array}{l}\text { Median } \\
\text { (range) }\end{array}$ & $\begin{array}{l}15(9- \\
24)\end{array}$ & $79(61-89)$ & $\begin{array}{l}92 \\
(81- \\
100)\end{array}$ & $\begin{array}{l}96.5 \\
(84- \\
99)\end{array}$ & $\begin{array}{l}72.5 \\
(55- \\
90)\end{array}$ & $\begin{array}{l}59.5 \\
(31- \\
75)\end{array}$ & $\begin{array}{l}80 \\
(66- \\
89)\end{array}$ & $\begin{array}{l}6.5 \\
(0- \\
11)\end{array}$ & & & \\
\hline
\end{tabular}

\section{Discussion}

Due to the limited regenerative capacity of articular cartilage, focal cartilage defects present as a difficult clinical challenge. If left untreated, the resulting fibrocartilage repair tissue has poor wear characteristics and a predilection for advancing arthritis[21]. The ideal treatment of focal articular cartilage lesions is one which restores organized hyaline cartilage through a single staged, costeffective, and minimally invasive method[17]. Several surgical techniques have been developed to address focal cartilage defects, though no single technique has been shown to reproduce normal hyaline cartilage[9].

Microfracture is considered first-line treatment for small $(<2 \mathrm{~cm})$ cartilage lesions given its technical ease, low cost, minimallyinvasive nature, and low morbidity[18]. However, biopsies of MF have demonstrated that the resulting cartilage was only $10 \%$ hyaline cartilage with the majority consisting of fibrocartilage[12]. OATS procedures attempt to restore cartilage defects by introducing mature, hyaline articular cartilage immediately, however, the procedure is not recommended in defects $>4 \mathrm{~cm}$ and donor site pain, infection risk, and iatrogenic cartilage damage can obscure an otherwise successful treatment[10]. OCA has emerged as a successful treatment with graft survivorship approaching $80 \%$ at 10 years[7]. However, OCA remains limited by cadaver availability, shelf life, and disease transmission[13]. The limitations of existing cartilage repair techniques have led to the emergence of several new biotechnologies, such as cartilage tissue engineering and regeneration.

Off-the-shelf osteochondral allografts such as Cartiform (Osiris), Chondrofix (Zimmer Biomet), and ProChondrix (AlloSource), have surfaced as alternatives to OATS and fresh OCAs[1]. These biomaterial scaffolds are seeded with appropriate cell types and inductive bioactive factors to produce a durable cartilage repair system which can be implanted in a single stage operation[20].

In addition to possessing living chondrocytes, ProChondrix ${ }^{\circledR}$ has been shown to express growth factors necessary for hyaline cartilage regeneration. In vitro analysis performed by Delaney et. al[16] demonstrated the presence of bFGF (Basic Fibroblast Growth Factor), PRG4 (Superficial Zone Protein), TGF- $\beta$ (Transforming Growth Factor Beta), IGF-1 (Insulin-Like Growth Factor 1), BMP-2 (Bone Morphogenic Protein 2), BMP-7 (Bone Morphogenic Protein 7) and PDGF (Platelet Derived Growth Factor) within ProChondrix ${ }^{\circledR}$ samples[16]. These growth factors can promote Bone Marrow Derived Cell (BMDC) migration into the surgical site after being liberated via microfracture and encourage chondrogenesis[16]. The porous biomaterial implant may further facilitate this mesenchymal stem cell migration and incorporation[1]. 
Although published clinical outcomes of ProChondrix ${ }^{\circledR}$ osteochondral allografts are limited, preliminary case reports have demonstrated promising results. In 2019, Beth et al.[2] described the use of ProChondrix ${ }^{\circledR}$ OCA in a 34 year old woman suffering an osteochondral defect of the talus. At 12 months postoperatively, the patient was performing preoperative activities without any discomfort and postoperative radiographs showed a resolved osteochondral defect (OCD) of the talus.

Like ProChondrix ${ }^{\circledR}$, Cartiform is a cryopreserved OCA that contains viable chondrocytes, extracellular matrix (ECM), and chondrogenic proteins. In a histological evaluation of Cartiform in a goat model, Geraghty et al.[8] revealed retained chondrocytes, chondrogenic growth factors, and ECM proteins within the graft at 3 months and 12 months follow-up. Furthermore, this study demonstrated when used in conjunction with microfracture, Cartiform results in improved cartilage growth and complete bony integration at 12 months, compared to microfracture alone. These studies suggest combination of a live cell-signaling matrix and migration of BMDCs lead to incorporation of the allograft and the formation of healthy hyaline cartilage.

In contrast to the cellular ProChondrix ${ }^{\circledR}$ and Cartiform osteochondral allografts, Chondrofix is a decellularized osteochondral allograft. In 2016, Farr et al.[11] reported a failure rate of $72 \%$ in a prospective series of 32 patients treated with Chondrofix with a mean follow-up of 1.29 years since implantation. Furthermore, the authors reported that given the acellular nature of Chondrofix, eventual graft failure was a likely outcome. In contrast, no patients included in our study experienced rejection or graft failure. These data suggest that the absence of viable chondrocytes in the Chondrofix OCA may have hindered graft integration.

To our knowledge, this is the first study to report the clinical outcome, activity level, and patient oriented outcomes in a case series of patients following treatment of an isolated cartilage defect with a ProChondrix $\circledast$ osteochondral allograft implant. Our study demonstrates promising short-term results as demonstrated by patient reported clinical outcome scores at median follow-up of 15 months (range 9-24 months). The KOOS subscales demonstrated favorable outcomes. These results are similar to studies evaluating alternative techniques for repair of focal cartilage defects. In 2013, Tompkins et al.[19] described a series of 13 patients undergoing a novel single-stage articular cartilage restoration procedure with DeNovo VT Graft with a mean follow-up of 28 months and a mean age of 26.4 years. The mean scores for each subdomain of the KOOS were as follows: 84.2 for pain, 85.0 for symptoms and stiffness, 88.9 for activities of daily living, 62.0 for sports and recreation, and 60.8 for quality of life. Similarly, our study demonstrates clinically meaningful patient-reported outcomes in KOOS symptoms, KOOS pain, KOOS activities of daily living, and KOOS sport as defined by the patient acceptable symptom state (PASS) threshold[14],[5]. Another similarity is that at the most recent clinical follow-up, all patients included in this study were pain free and had returned to preoperative activity level.

Our study has several limitations. Most notably, we reported a small number of patients in a short-term case series without a control group. Despite the few patients in this study, we believe it is important to report the early results for this procedure, for which there is limited published information to date. Due to the retrospective nature of this study, KOOS and Marx activity scale scores were only obtained postoperatively, and we did not have any preoperative data available. This limitation prevented us from measuring the preoperative to postoperative improvement in KOOS or Marx activity scores. Despite these limitations, our findings demonstrate promising outcomes in an emerging field with limited clinical data.

\section{Conclusion}

This case series of six patients who underwent repair of cartilage defects in the knee with a ProChondrix ${ }^{\circledR}$ osteochondral allograft has demonstrated clinically meaningful patient reported clinical outcomes at short-term follow-up.

\section{Abbreviations}

microfracture (MF),

autologous chondrocyte implantation (ACl),

osteochondral autograft (OATS)

osteochondral allograft (OCA) 
patient-reported outcome (PRO)

Knee injury and Osteoarthritis Outcome Score (KOOS)

bFGF (Basic Fibroblast Growth Factor)

PRG4 (Superficial Zone Protein)

TGF- $\beta$ (Transforming Growth Factor Beta)

IGF-1 (Insulin-Like Growth Factor 1)

BMP-2 (Bone Morphogenic Protein 2)

BMP-7 (Bone Morphogenic Protein 7)

PDGF (Platelet Derived Growth Factor)

Bone Marrow Derived Cell (BMDC)

osteochondral defect (OCD)

extracellular matrix (ECM)

patient acceptable symptom state (PASS)

\section{Declarations}

Funding: No funding was received for conducting this study.

Ethics approval: According to the policy defining activities which constitute research at our institution, this work met criteria for operational improvement activities exempt from ethics review.

Consent to participate: All subjects included in this study written informed consent.

Consent for publication: All subjects included in this study written informed consent for publication.

Availability of data and material: N/A

Competing interests: James Slauterbeck, MD reports research consultation for AlloSource.

Authors' contributions: All authors contributed to the study conception and design. The first draft of the manuscript was written by Michael Barnum and all authors commented on previous versions of the manuscript. All authors read and approved the final manuscript.

\section{References}

1. Beer AJ, Tauro TM, Redondo ML, Christian DR, Cole BJ, Frank RM. Use of Allografts in Orthopaedic Surgery: Safety, Procurement, Storage, and Outcomes. Orthop J Sports Med. 2019;7:2325967119891435.

2. Beth ZC, Sachs B, Kruse D, Stone PA. Arthroscopic Implantation of a Cartilage Matrix for an Osteochondral Defect of the Talus: A Case Report. J Foot Ankle Surg. 2019;58:1014-8.

3. Bhosale AM, Richardson JB. Articular cartilage: structure, injuries and review of management. Br Med Bull. 2008;87:77-95.

4. Churchill JL, Krych AJ, Lemos MJ, Redd M, Bonner KF. A Case Series of Successful Repair of Articular Cartilage Fragments in the Knee. Am J Sports Med. 2019;47:2589-95. 
5. Connelly JW, Galea VP, Rojanasopondist P, Matuszak SJ, Ingelsrud LH, Nielsen CS, et al. Patient Acceptable Symptom State at 1 and 3 Years After Total Knee Arthroplasty: Thresholds for the Knee Injury and Osteoarthritis Outcome Score (KOOS). J Bone Joint Surg Am. 2019;101:995-1003.

6. Curl WW, Krome J, Gordon ES, Rushing J, Smith BP, Poehling GG. Cartilage injuries: a review of 31,516 knee arthroscopies. Arthroscopy. 1997;13:456-60.

7. Familiari F, Cinque ME, Chahla J, Godin JA, Olesen ML, Moatshe G, et al. Clinical Outcomes and Failure Rates of Osteochondral Allograft Transplantation in the Knee: A Systematic Review. Am J Sports Med. 2018;46:3541-9.

8. Geraghty S, Kuang JQ, Yoo D, LeRoux-Williams M, Vangsness CT Jr, Danilkovitch A. A novel, cryopreserved, viable osteochondral allograft designed to augment marrow stimulation for articular cartilage repair. J Orthop Surg Res. 2015;10:66.

9. Grande DA, Schwartz JA, Brandel E, Chahine NO, Sgaglione N. Articular Cartilage Repair: Where We Have Been, Where We Are Now, and Where We Are Headed. Cartilage. 2013;4:281-5.

10. Hangody L, Fules P. Autologous osteochondral mosaicplasty for the treatment of full-thickness defects of weight-bearing joints: ten years of experimental and clinical experience. J Bone Joint Surg Am 85-A Suppl. 2003;2:25-32.

11. Johnson CC, Johnson DJ, Garcia GH, Wang D, Pais M, Degen RM, et al. High Short-Term Failure Rate Associated With Decellularized Osteochondral Allograft for Treatment of Knee Cartilage Lesions. Arthroscopy. 2017;33:2219-27.

12. Knutsen G, Engebretsen L, Ludvigsen TC, Drogset JO, Grontvedt T, Solheim E, et al. Autologous chondrocyte implantation compared with microfracture in the knee. A randomized trial. J Bone Joint Surg Am. 2004;86:455-64.

13. Liu YW, Tran MD, Skalski MR, Patel DB, White EA, Tomasian A, et al. MR imaging of cartilage repair surgery of the knee. Clin Imaging. 2019;58:129-39.

14. Muller B, Yabroudi MA, Lynch A, Lai CL, van Dijk CN, Fu FH, et al. Defining Thresholds for the Patient Acceptable Symptom State for the IKDC Subjective Knee Form and KOOS for Patients Who Underwent ACL Reconstruction. Am J Sports Med. 2016;44:2820-6.

15. Richter DL, Schenck RC Jr, Wascher DC, Treme G. Knee Articular Cartilage Repair and Restoration Techniques: A Review of the Literature. Sports Health. 2016;8:153-60.

16. Ryan Delaney M, Carolyn Barrett B, Peter Stevens PhD M. (2016) ProChondrix ${ }^{\circledR}$ cartilage restoration matrix contains growth factors necessary for hyaline cartilage regeneration.

17. Sgaglione NA. The future of cartilage restoration. J Knee Surg. 2004;17:235-43.

18. Steadman JR, Rodkey WG, Rodrigo JJ. (2001) Microfracture: surgical technique and rehabilitation to treat chondral defects. Clin Orthop Relat Res;10.1097/00003086-200110001-00033S362-369.

19. Tompkins M, Hamann JC, Diduch DR, Bonner KF, Hart JM, Gwathmey FW, et al. Preliminary results of a novel single-stage cartilage restoration technique: particulated juvenile articular cartilage allograft for chondral defects of the patella. Arthroscopy. 2013;29:1661-70.

20. Tuan RS, Chen AF, Klatt BA. Cartilage regeneration. J Am Acad Orthop Surg. 2013;21:303-11.

21. Willers C, Wood DJ, Zheng MH. A CURRENT REVIEW ON THE BIOLOGY AND TREATMENT OF ARTICULAR CARTILAGE DEFECTS (PART I \& PART II). Journal of Musculoskeletal Research. 2003;07:157-81. 